\title{
Relationship between Job Satisfaction and Turnover Intention: Evidence from Bangladesh
}

\author{
Shaikh Moksadur Rahman \\ Professor, Department of Management Studies, Comilla University, Cumilla-3506, BANGLADESH \\ *E-mail for correspondence: rahman392@yahoo.com
}

https://doi.org/10.18034/abr.v10i2.470

\begin{abstract}
Nowadays job satisfaction and turnover intention are the most important and widely researched variables. Job satisfaction increases the loyalty and professional commitment to the organization which leads to productivity. On the other hand turnover intention has serious negative consequences for effective organizational operations. The purpose of this exploratory study is to find out the relationship between job satisfaction and turnover intention of employees working in some selected sectors in Cumilla, Bangladesh. The study considered a sample of 355 employees across various sectors to find out the different opinion about the levels of their satisfaction related factors and turnover intention. For the purpose of in-depth analysis, statistical tools, inter-correlation matrix and multiple regression technique had been used. The results indicate that there were significant inverse relationship between job securityturnover intention, pay-turnover intention, and promotion-turnover intention. The results will help organizations understand how to address employees' demands and concerns toward their jobs and discover successful ways of retaining them. This in turn will reduce turnover rate and the associated costs.
\end{abstract}

Key words: Job satisfaction; job security, pay-turnover intention; promotion-turnover intention, Bangladesh

\section{INTRODUCTION}

A wide attention has been paid to employees' attitudes in organizational behavior recently. Employees' attitudes such as job satisfaction and turnover intention are associated with many important behaviors and outcomes for employees that have implication for organization and personal well-being (Spector 1985; Meyer et al. 2002; Alshitri, 2013). Several studies indicate that satisfied employees are committed to the organization, they represent value to the work place and that they are the most important agents for continuous improvement. Satisfied employees are more likely to deliver better products and services, which results in better outcomes and higher customer satisfaction and loyalty (Eskildsen and Dahlgaard, 2000; Sowmya, 2013; Alshitri, 2013).

Job satisfaction has been studied intensively in the west, but only a few studies have been conducted in nonwestern nations. Indeed, job satisfaction has been a matter of growing interest for those concerned with the quality of working life and organizational efficiency. The consequences of job satisfaction are very important to an organization in terms of its efficiency, productivity, employee relations, absenteeism, accident and turnover (Brierley, 1999; Maghrabi, 1999; Blum and Naylor, 2004; Lu et al., 2005; Spector, 2006). Hoppock and Spiegler (1938) defined job satisfaction as employees' emotion and attitude toward their jobs, and is their subjective reaction. Job satisfaction can be defined as the characteristics of the job itself and the work environment in which employees may find rewards, satisfaction, or conversely, the dissatisfaction (Abdulla et al. 2011). In addition Ngamkroeckjotia et al. (2013) has stated that job satisfaction is the attitudes towards the organization, coworkers, job and other psychological objects among workers in the work environment. Furthermore, Sowmya (2013) and Muralidharan (2013) defined job satisfaction as the factor relates to workers' opinions regarding their jobs and their employees. In addition, job satisfaction is referred to the positive emotion resulting from the appraisal of one's job characteristics and experiences. According to Amah (2009), organization must know to motive their employees, because more satisfied 
employees' clock in more profits, there is lower employee turnover, and this leads to high productivity.

According to Management and OB literature (Maghrabi, 1999; Blum and Naylor, 2004; Lu et al. 2005; Spector, 2006; Rahman, 2012; Wu, 2012 Alshitri, 2013; Sowmya, 2013; Rahman, 2017), job satisfaction is influenced by work related factors such as: nature of work, pay, promotion, boss, co-worker, physical environment, organizational policies, affective commitment, continuance commitment, normative commitment etc. It also affected by demographic factors such as; age, sex, race, religion, marital status, educational qualifications, year of experience, organizational status etc. Different studies identified that (Blum and Naylor, 2004; Lu et al. 2005; Spector, 2006; Rahman, 2012; Alshitri, 2013; Sowmya, 2013; Muralidharan, et al. 2013) less job satisfaction leads increasing turnover rate. It is also found that less satisfied or dissatisfied employees' sometimes stay in the organization due to not having alternative way. The behavior of these employees is as 'wild bird in the cage' which always search the opportunity to fly away.

\section{LITERATURE REVIEW}

The term 'job satisfaction' is likely to be the most widely research topic about work attitudes over the last eighty years. Therefore, this term is not unfamiliar to the reader. A large number of researchers have examined the job satisfaction in different dimensions, their concluded results were different. Beecham et al. (2008) indicated that job satisfaction is simply how people feel about their jobs in different aspects. It is the extent to which people like (satisfaction) or dislike (dissatisfaction) their jobs. Similar, job satisfaction is defined as the extent to which employees like their job by Agho and Price in 1992. However, the most widely accepted explanation of job satisfaction as a pleasurable or positive emotional state resulting from the appraisal of one's job or job experience (Spector, 2006; Droussiotis and Austin, 2007).

Furthermore, Lim (2008); Wu (2012) suggested that job satisfaction had significant influence whether individual or organization. On the contrary, when employees are not satisfied, they tend to shift and look for satisfaction elsewhere. It may leads to employee's various reaction, no matter be psychological or action (Joo and Park, 2010). The most common is the employee turnover (Beecham et al. 2008). Job satisfaction has been linked to productivity, motivation, physical health, and general life satisfaction (Gunlu et el. 2010). It can be divided into two types which are based on the level of employees' feelings regarding their jobs. They are global job satisfaction (focus on employees' overall feelings about their jobs). It is the overall evaluation on job satisfaction. And job facet satisfaction (focus on feelings about specific job aspects, such as salary, supervisor support, and the quality of relationships with one's co-workers (Mueller and Kim, 2008; $\mathrm{Wu}, 2012$ ).

Nauman (1992); Wu (2012), Cave et al. (2013) define that turnover means that an individual leaves the organization and goes elsewhere for similar or another job. Muller and Kim (2008) mention that turnover intention is referred as an individual's estimated probability that they will stay at the current organization. According to the American KepnerTregoe consulting service company's research, based on the turnover cost of IT professionals, an employee's turnover will directly cause the company financial losses of at least $25 \%$ above the departed employee's annual income (Cave et al, 2013). Aiken et al. (2001) conducted a study on nurse and found job dissatisfaction among nurses was highest in the United States $(41 \%)$ followed by Scotland $(38 \%)$, England $(36 \%)$, Canada $(33 \%)$ and Germany $(17 \%)$. One third of nurses in England and Scotland and more than one fifth in the United States planned on leaving their job within 12 months of data collection. More striking, however, was that $27-54 \%$ of nurses less than 30 years of age planned on leaving within 12 months of data collection in all countries. Regarding the work climate, only about one third of nurses in Canada and Scotland felt that they participated in developing their own work schedules in comparison with more than half in the other three countries. A large number of scholars have determined that intent to stay in the organization or leave is strongly and consistently related to voluntary turnover (Mathieu and Zajac, 1990; Wright and Bonett, 2007). Wu (2012); Cave et al. (2013) suggested that most organizational research of turnover is voluntary quits.

Several studies have tried to identify the relationship between job satisfaction and turnover intention. There are inverse relationship between these two variables (Sowmya, 2013; Cave et al., 2013; Muralidharan et al., 2013). Trevor (2001) determined that job satisfaction plays a major role in most theories on turnover while Amah (2009); Cave et al. (2013) indicate that the various dimensions of job satisfaction and turnover intention are both obviously and negatively correlated. Hence, it is clear that increasing the repatriate's job satisfaction is paramount in attempting to reduce their intention to leave the company. Job satisfaction is the positive emotional response to a job situation resulting from attaining what the employee wants and values from a job (Wu, 2012). In meta-analysis, Spector (2006) found a significant negative correlation of -.26 between job satisfaction and turnover. Similarly, Hellman (1997); Brierley (1999); Judge et al. (2001) conducted a meta-analysis and found the relationship between job satisfaction and intent to leave was significantly different from zero and consistently negative. 


\section{ReLEVANCE OF THE STUdy}

A sound system of industrial relations and the maintenance of industrial peace is an important prerequisite for any developing economy. The harmonious relationship between the management and the workers has a vital role in the establishment of industrial discipline, industrial democracy and industrial peace and it has a far reaching impact on productivity, labor efficiency and social welfare (Locke, 1983; Anthony et al. 2001, Jesily, 2013; Poorna and Anandaraj, 2013). Industrial relations denote a highly complex and dynamic process of relationship involving the workers and the management as well as their collective forums and the state. A number of studies (Mueller and Kim, 2008; Gunlu et el. 2010; Wu, 2012) found that due to not having alternative way, many dissatisfied employees constitutes their job in same organization. Thus, the absence of turnover does not mean that the complete peace prevails in the mind of employees.

The economy of Bangladesh comprises with three sectors such as: Agriculture, industry and service. After its liberation since 1971, industrial and service sector are being considered as the growing sectors of economy by creating huge employment opportunities, income generation and sustainable development. The contribution of industry and service sectors to GDP in $2015-16$ were $28.77 \%$ and $56.46 \%$, respectively (BBS, 2016). Although the growth rates are higher than agricultural sector, these two sectors are facing immense problems like employee turnover due to poor job satisfaction hindering its optimal growth. The studies, conducted on job satisfaction in Bangladesh, India, Pakistan, Iran and many other Asian countries concerning with turnover intention with specific group of people rather than people of various sectors. So there is a need to find the impact of work related factors on job satisfaction and turnover intention in industrial and service sectors simultaneously of Bangladesh. The researcher hopes that finding of this study will add value as sample research from a developing world country like Bangladesh.

\section{ObJectives of the Study}

The study was undertaken with the following objectives in mind:

- To identify the variables affecting the job satisfaction in different sectors;

- To classify the employees on the basis of the perception of job satisfaction; and

- To identify the relationship between the factors related to job satisfaction and turnover intention.

\section{MATERIAL AND METHODS}

\section{Sample}

The data for this study was primarily collected through a structured questionnaire to elicit the opinion of the respondents, and the secondary data were collected from scholarly articles published in different journals, books, reports, monographs, thesis and relevant websites. Using the simple random sampling technique, a total of 550 respondents were selected as a sample of the study from greater Cumilla district (greater Cumilla districts comprises with three administrative districts: Cumilla, Chandpur and Brahmanbaria) in order to have varied opinion about job satisfaction and turnover intention in construction, banking, medical and manufacturing sectors during the period of January - December' 2018. A total of 550 questionnaires, out of which 355 usable questionnaires were used for the present study. The remaining questionnaires were either unreturned or incompleted. In the scrutinizing process, among 355 respondents, it was found that the respondents were $21 \%$, $27 \%, 24 \%$ and $28 \%$ from construction, banking, medical and manufacturing sectors, respectively. Table 1 shows the respondents' profile.

\section{Instrument and measurement}

To measure the job satisfaction, ten variables; job security, nature of work, pay, promotion, co-worker, boss, job in general, physical environment, organizational commitment (affective commitment, continuance commitment and normative commitment) and demographic factors are considered. Firstly, Smith, Kendall, and Hulin developed the JDI in 1969. Smith et al. argue that that job satisfaction is composed of five different areas: work on present job, present pay, and opportunities for promotion, supervision, and people on your present job. Validity and reliability of each of the scales is discussed in the literature review of the Job Descriptive Index (Maghrabi, 1999; Skibba, 2002). Besides these, job in general scale is also included in JDI. A brief description of each of the ten areas are follows.

\section{Job security}

A good job security system can enhance satisfaction, thereby reducing the intention of looking for other jobs and turnover. Job security satisfaction as a feeling and evaluation of the employees to the corporate welfare system will have an important impact on employees' attitudes and behavior. From the perspective of the development of human resources practice, organizations take actions which are conducive to their secured job. Job securities by the employer have many other consequences; it reduces job related stress and induces satisfaction. Human resource management theory has showed the correlation of job security and employee turnover intention was significantly negative. Many of the employees regardless the nationalities worry about the security of their job rather than substantial amount of monthly or yearly salary.

\section{Nature of work}

This scale is designed to measure how people feel about the job they are currently doing. It measures how satisfied an employee is with the work. The questions related to this area are designed to measure the different facets of a 
job including: "opportunities for creativity and task variety, allowing an individual to increase his or her knowledge, and changes in responsibility, amount of work, autonomy, job enrichment and job complexity."

\section{Pay}

This scale measures how a people feel with their pay and the difference between what a people are actually getting and what they believe they should be getting. This area is influenced by various factors: the pay of employees doing the same job, the financial situation of the employee, the pay the employee received on previous jobs, and the economy.

\section{Promotion}

This scale measures how the employees feel about the procedures that the administration follows in accordance with giving promotions. The different factors that create satisfaction with promotions are "frequency of promotions, the importance of promotions, and the desirability of promotions."

\section{Co-workers}

This scale looks at the relationship and satisfaction that the employees have with their co-workers. This area of satisfaction is measured by how well employees get along with each other and how well they look up to their fellow employees.

\section{Boss}

This scale of the JDI measures how satisfied people are with their supervisors. Typically, if supervisors are employee-centered, meaning that they take interest in their employees and listen to them, than the employees are more satisfied with their supervisors. Employees also find more satisfaction with supervisors if the supervisors are deemed competent with their job.

\section{Job in General (JIG)}

The Job in General scale is a measure that is included with the Job Descriptive Index. The scale was developed to assess the overall satisfaction of people with their jobs. The JDI measures the different areas for satisfaction. The Job In General is also designed to measure employees' satisfaction with their jobs. The JIG is a measure of global satisfaction, meaning that participants are asked to think about how satisfied they are with their job in a broad, overall sense.

\section{Physical environment}

This scale measures how the employees feel about the inside and outside physical environment such as plant layout, safety measures, interior decoration, ventilation, illumination, noise, structural facilities etc.

\section{Organizational Commitment}

Organizational commitment refers as a psychological attachment of an employee to an organization, It makes employee willing to sacrifice their own emotion for the organization and more loyal to organization. It includes affective commitment, continuance commitment and normative commitment. Affective Commitment: the relative strength of an individual's identification with and involvement in a particular organization. Continuance Commitment: the extents to which employees feel commitment to their organizations when they consider the costs of leaving the organization. Normative Commitment: means employee stay with organization just because it's a right thing based on their personal norms such as moral then realized the organizational goals.

\section{Demographic factors}

The reviews of literature of demographic factor variables that have been found to have stable relationship with job satisfaction, retention and turnover intentions are age, sex, race, religion, marital status, educational qualifications, year of experience, organizational status etc. Demographic factors have been chosen because they have an influence on employee retention strategies. Several studies in which demographic factors have been employed to investigate job satisfaction and job attitudes have shown that they are strong predictors of turnover intentions.

\section{Job satisfaction}

The Job Descriptive Index (including the job in general) assesses an individual's job satisfaction on six scales composed of from 9 to 18 short phrases or adjectives, their total number is 90. (Nature of work: 18, pay: 9, Promotion: 9, co-worker: 18, boss: 18, and Job in General: 18). Moreover, on the basis of literature survey, the following scales contain the following short phrases, job security: 6, physical environment: 7, organizational commitment: 11 and demographic factors: 8 . The questionnaire used in this study had five-point Likert scale ranging from strongly agree, agree, neutral, disagree and strongly disagree. The ten variables are scored separately and measured satisfaction. The word with positive description or phrase in the variables was measured with five-points for 'strongly agree' representing very satisfied (score: 5) and strongly disagree representing very dissatisfied (score: 1). For negative descriptive phrase or adjective, they were also measured with five-points for 'strongly agree' representing very dissatisfied (score: 1) and strongly disagree representing very satisfied (score: 5 ). Hence, if the summed score is greater than 3, it indicates that the respondent has achieved satisfaction with the work related variables. Reversely, if the summed score is less than 3 , it reveals that the respondent has dissatisfaction.

\section{Turnover intention}

The turnover intention scale (TIS-6) is a six-item scale adapted by Roodt (2004) from his unpublished 15-item turnover intention scale as a measure for assessing employees' intentions of either staying with or leaving an organization. The scale was previously tested and it was found to be reliable and valid (Giffen, 2015). Although turnover intentions have been thoroughly covered in the literature, previous studies employed questionnaires with a relatively small number of items to measure turnover intentions. For example, some previous researchers have used a single-item scale (Lambert et 
al., 2001) while others deployed a three -item scale (Becker, 1992; Fox and Fallon, 2003). As the meanings of the items used in the scale is very close to each other, for example, "I often think about quitting my present job," and "I will probably not stay with this organization for much longer." The turnover intention scale was turned into five items and used here, they were: "I sometime put in less effort in my work than what I required," "Sometimes, I postpone important duties for an unlimited period of time," "I am trying to get another job within this organization," "I am trying to leave this organization," and "I am starting to look for other job."

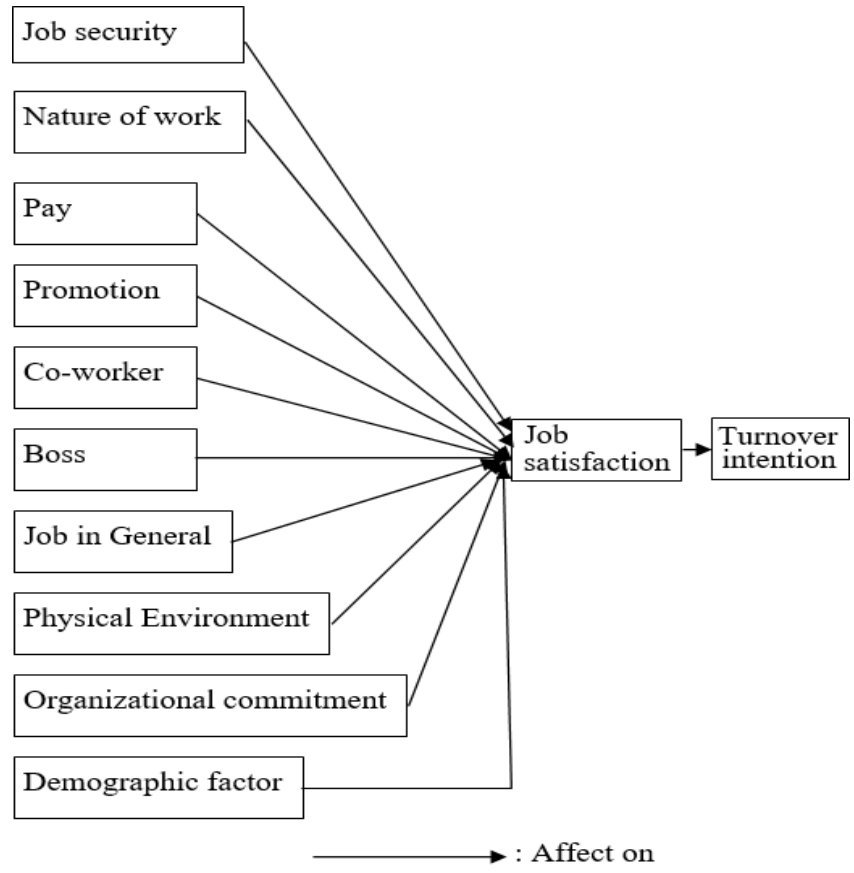

Figure: Study Framework

\section{Measurement of Validity}

The purposes of validity test are to determine the validity and accuracy of the questionnaire. In order to achieve more accurate item-objective congruence has been used to measure the validity of the questionnaires in this study. It was handed to seven colleagues working in the same field who helped making comments, giving scores, reviewing and making correction. If the score over than 0.70, it means that the item are valid. If the score equal or less than 0.70 means that the items objective is congruence or invalid (Radhakrishna, 2007).

\section{Measurement of Reliability}

To ensure the reliability of this research instrument, the factors affected to job satisfaction was tested for each of the ten variables by using Cronbach's alpha average resulted 0.751 and 0.843 for job satisfaction and turnover intention, respectively. Cronbach's alpha reliability coefficient normally ranges between 0 and 1 . However, there is actually no lower limit to the coefficient. The closer Cronbach's alpha coefficient is to 1.0 the greater the internal consistency of the items in the scale. George and Mallery (2009) provide the following rules of thumb: " $\geq$ 0.9 - Excellent, $\geq 0.8$ - Good, $\geq 0.7$ - Acceptable, $\geq 0.6$ Questionable, $\geq 0.5$ - Poor, and $\leq 0.5$ - Unacceptable."

\section{Tools of Analysis}

Respondents' profile was reported in percentages value. Turnover intention containing ten dimensions (independent variables) were presented by descriptive statistics. For the purpose of in-depth analysis, statistical tools, inter-correlation matrix and multiple regression technique had been used. The data analysis was done by using SPSS 20.0 version.

Table 1: Respondents' Profile $(\mathrm{n}=355)$

\begin{tabular}{|l|l|l|l|l|l|}
\hline Particulars & Number & Percentage & Characteristic & Number & Percentage \\
\hline Age (year): & & & Education: & & \\
\hline$<25$ & 55 & $(15.49 \%)$ & College & 128 & $(36.06 \%)$ \\
\hline $25-30$ & 33 & $(9.30 \%)$ & University & 227 & $(63.94 \%)$ \\
\hline $30-35$ & 111 & $(31.27 \%)$ & Position: & & \\
\hline $35-40$ & 75 & $(21.13 \%)$ & Junior level & 147 & $(41.41 \%)$ \\
\hline$>40$ & 81 & $(22.82 \%)$ & Mid-level & 177 & $(49.86 \%)$ \\
\hline Sex: & & & Senior level & 31 & $(8.73 \%)$ \\
\hline Male & 309 & $(87.04 \%)$ & Nature of organization: & & \\
\hline Female & 46 & $(12.96 \%)$ & Construction & 65 & $(18.31 \%)$ \\
\hline Working tenure (year): & & & Banking & 106 & $(29.86 \%)$ \\
\hline$<5$ & 50 & $(14.08 \%)$ & Medical & 85 & $(23.94 \%)$ \\
\hline $5-10$ & 86 & $(24.23 \%)$ & Manufacturing & 99 & $(27.89 \%)$ \\
\hline $10-15$ & 98 & $(27.61 \%)$ & & & \\
\hline $15-20$ & 47 & $(13.24 \%)$ & & & \\
\hline$>20$ & 74 & $(20.85 \%)$ & & & \\
\hline
\end{tabular}




\section{RESULT AND DISCUSSION}

The perception of the employees on each of the satisfaction related factors was analyzed with the help of descriptive statistics. The total scores of all the 355 employees were summed up separately for each factor and the mean value was calculated for each factor. The table 2 shows the minimum, maximum, mean, standard deviation and rank for each of the selected variables as per the perception of the employees. The table shows that job satisfaction related factors were not rated equally by the employees. The 'demographic factor' with a mean value 4.18 was the rank 1 factor among all.
Table 2: Minimum, Maximum, Mean, Standard Deviation and Rank of Independent Variables

\begin{tabular}{|l|c|c|c|c|c|}
\hline Independent variables & Min & Max & Mean & $\begin{array}{c}\text { Std. } \\
\text { Dev }\end{array}$ & Rank \\
\hline Job security & 1.50 & 4.80 & 2.70 & 0.80 & 9 \\
\hline Nature of work & 1.70 & 5.00 & 3.25 & 0.88 & 5 \\
\hline Pay & 1.60 & 4.70 & 2.75 & 0.72 & 8 \\
\hline Promotion & 1.80 & 5.00 & 2.90 & 0.67 & 7 \\
\hline Co-worker & 1.70 & 4.80 & 3.10 & 0.91 & 6 \\
\hline Boss & 1.00 & 4.95 & 3.56 & 0.76 & 4 \\
\hline Job in General & 1.90 & 4.70 & 2.46 & 0.69 & 10 \\
\hline Physical Env. & 2.00 & 5.00 & 3.67 & 0.73 & 3 \\
\hline Organizational Com & 1.50 & 4.55 & 3.80 & 0.89 & 2 \\
\hline Demographic factor & 2.10 & 5.00 & 4.18 & 0.76 & 1 \\
\hline
\end{tabular}

Table 3: Inter-correlation Matrix for Job Satisfaction Factors and Turnover Intention

\begin{tabular}{|c|c|c|c|c|c|c|c|c|c|c|c|}
\hline Variable & $\mathrm{Y}$ & $\mathrm{X} 1$ & $\mathrm{X} 2$ & $\mathrm{X} 3$ & $\mathrm{X} 4$ & X5 & $\mathrm{X} 6$ & $\mathrm{X} 7$ & $\mathrm{X} 8$ & $\times 9$ & X10 \\
\hline TI & 1.00 & & & & & & & & & & \\
\hline JS & $-0.567^{* *}$ & 1.00 & & & & & & & & & \\
\hline NW & -0.104 & $0.404^{* *}$ & 1.00 & & & & & & & & \\
\hline $\mathrm{P}$ & $-0.509^{* *}$ & 0.139 & 0.109 & 1.00 & & & & & & & \\
\hline Pro & $-0.485^{*}$ & $0.405^{* *}$ & $0.409^{* *}$ & $0.395^{* *}$ & 1.00 & & & & & & \\
\hline CoW & $-0.413^{* *}$ & 0.113 & 0.098 & 0.097 & $0.180^{*}$ & 1.00 & & & & & \\
\hline B & $-0.355^{*}$ & 0.065 & 0.143 & 0.098 & 0.102 & $0.189^{*}$ & 1.00 & & & & \\
\hline JIG & $-0.277^{*}$ & 0.207 & 0.097 & $0.388^{* *}$ & $0.445^{* *}$ & 0.087 & 0.112 & 1.00 & & & \\
\hline PE & -0.167 & 0.167 & 0.078 & 0.099 & 0.087 & 0.124 & $0.189^{*}$ & $0.248^{*}$ & 1.00 & & \\
\hline OC & $-0.342^{*}$ & 0.142 & 0.133 & 0.123 & 0.056 & 0.088 & $0.321^{* *}$ & 0.150 & $0.456^{* *}$ & 1.00 & \\
\hline DF & $-0.547^{* *}$ & $0.247^{*}$ & 0.137 & 0.111 & 0.077 & $0.328^{* *}$ & 0.115 & 0.163 & 0.078 & 0.097 & 1.00 \\
\hline
\end{tabular}

TI: Turnover Intention, JS: Job Security, NW: Nature of Work, P: Pay, Pro: Promotion, CoW: Co-Worker, B: Boss, JIG: Job in General, PE: Physical Environment, OC: Organizational Commitment, DF: Demographic Factor.

${ }^{*}$ Correlation in significant at the 0.05 level (2-tailed); ${ }^{* *}$ Correlation is the significant at the 0.01 level (2-tailed).

As per table 3, the eleven variables (one dependent and ten independent variables) selected for the study were negatively correlated with one another through intercorrelation matrix analysis. The table shows eight factors, namely, 'job security', 'pay', 'promotion', 'co-workers', 'boss', 'job in general', 'organizational commitment' and 'demographic factor' were negatively correlated. Among them 'job security', 'demographic factor', 'pay', 'promotion' and 'co-workers' were highly significant. However, the inter-correlation matrix shown in table 3 cannot clearly state whether the correlation was genuine or false, as these were only zero-order correlation and also because there may be a multi-collinearity among the ten variables. As stated earlier, one of the objectives of the analysis was to identify the combination of job satisfaction related factors, which together were most critical in explaining variations in turnover intention. Therefore, these correlations were subjected to multi-variant analysis using step-wise multiple regression technique.

The ANOVA table was prepared for testing the overall statistical significance of the factors (Table 4). The table shows that the regression as a whole was significant.
Hence, it was statistically possible to proceed with the multiple regression technique.

Table 4: ANOVA ${ }^{\mathrm{a}}$ Table for Testing Multiple Regression

\begin{tabular}{|c|c|c|c|c|c|}
\hline Source & $\begin{array}{c}\text { Sum of } \\
\text { Squares }\end{array}$ & Df & $\begin{array}{c}\text { Mean } \\
\text { Square }\end{array}$ & F & Sig. \\
\hline Regression & 277.481 & 9 & 30.831 & 45.061 & $0.000^{\mathrm{b}}$ \\
\hline Residual & 236.051 & 345 & .684 & & \\
\hline Total & 513.532 & 354 & & & \\
\hline
\end{tabular}

a. Dependent Variable: Turnover Intention

b. Predictors: (Constant), Job Security, Nature of Work, Pay, Promotion, Co-worker, Boss, Job in General, Physical Environment, Organizational Commitment and Demographic Factor.

The multiple regression analysis shown in Table 5 indicates that there were three variables namely, 'job security', 'pay', and 'promotion' which met all the conditions in the selection of the criteria. Out of these three variables, 'job security' contributed more towards turnover intention, i.e. for every one unit change in 'job security', by keeping all other independent variables constant, it would result in (-) 0.391 unit change in 
turnover intention. It was followed by 'pay' and 'promotion' and they contributed to the extent of $(-) 0.385$ and (-) 0.290 unit change respectively in turnover intention for every one unit change in them. The independent variables accounted for $58.5 \%$ of the variations in the total variations of the dependent variable. As shown in the Table 5, the job satisfaction related factors such as 'nature of work', 'co-worker', 'boss', 'job in general', 'physical environment', 'organizational commitment' and 'demographic factor' had no significant influence on the turnover intention.

Table 5: Multiple Regression Analysis for Job Satisfaction Factors

\begin{tabular}{|l|c|c|}
\hline Variable & Beta & Regression t value \\
\hline JS & $-0.391^{* *}$ & -6.416 \\
\hline NW & -0.098 & -0.153 \\
\hline P & $-0.385^{* *}$ & -4.174 \\
\hline Pro & $-0.290^{*}$ & -3.896 \\
\hline CoW & -0.124 & -0.112 \\
\hline B & -0.109 & -0.549 \\
\hline JIG & -0.088 & -0.453 \\
\hline PE & -0.115 & -1.108 \\
\hline OC & -0.074 & -0.149 \\
\hline DF & -0.099 & -0.153 \\
\hline$R^{2}$ & 0.585 & \\
\hline Adjusted $R^{2}$ & 0.512 & \\
\hline$n$ & 355 & \\
\hline
\end{tabular}

Dependent variable: Turnover Intention,

*Significant at the 0.05 level (2-tailed);

**Significant at the 0.01 level (2-tailed).

The above analysis elucidated that three variable were statistically significant and negative related to the turnover intention, 'job security' was the most important factors among the three variables, it was followed by factors such as 'pay' and 'promotion.' Therefore, it is clear that unless the issue on 'job security', 'pay, and 'promotion' of the stated organizations were met adequately and on the priority basis, any attempt for the improvement of other factors may not result in establishing suitable employee structure.

\section{ConCLusion}

Current study focuses on the job satisfaction related factors and there influences on turnover intention of some selected organizations. The study shows that all factors do not have the equal impression on turnover intention. The empirical results of this study suggest that job security, pay and promotion have significantly negative effects on turnover intention. If the studied organizations can improve the situation of job security, pay structure and promotion policy, turnover intention can be effectively reduced. The employees were dissatisfied with regards to the job security, pay and promotion and these were found to be the critical job satisfaction related factors in affecting turnover intention adversely. However, nature of work, co-worker, boss, job in general, physical environment, organizational commitment and demographic factors, have no significant effect on turnover intention.

\section{LIMITATIONS AND SUggESTIONS FOR FUTURE RESEARCH}

This study used ten independent variables as mentioned in the 'material and methods' section. Literature on turnover intention depicts, it might be affected by the social-economic condition, emotional well-being and handling the personal life. The selected ten variables might not be the adequate for the job satisfaction related factors. It is possible that the employees of the selected organizations in the study did have nothing, relatively low, moderate and high levels of turnover intention but perhaps have absolutely higher turnover intention levels originating from socio-economic condition, emotional well-being and personal life. Therefore, future research should include the above mentioned factors in assessment of turnover intention and their effects. Finally, a large number of samples in various locations with multidimensional conditions should be investigated in order to make the generalization of the results.

\section{REFERENCES}

Abdulla J., Djebarni R., and Mellahi K. (2011). Determinants of job satisfaction in the UAE: A case study of the Dubai police, 40, 126-146.

Agho, A.O. and Price, J.L. (1992). Discriminant validity of measures of job satisfaction, positive affectivity and negative affectivity. Journal of Occupational and Organizational Psychology, 65 (4), 185-97.

Aiken, L., Clarke, S., Sloane, D., Sochalski, J., Busse, R.,Clarke, H., Giovannetti, P., Hunt, J., Rafferty, A., Shamian, J., 2001. Nurses' reports on hospital care in five countries. Health Affairs 20 (3), 43-53.

Alshitri, K.I. (2013). An Investigation of Factors Affecting Job Satisfaction among R\&D Center Employees in Saudi Arabia, Journal of Human Resources Management Research, Vol, 2013, Pp: 1 - 10.

Amah, O.E. (2009). Job Satisfaction and Turnover Intention Relationship: The Moderating Effect of Job Role Centrality and Life Satisfaction. Research and Practice in Human Resource Management, 17(1), 24-35.

Anthony, W. P., Perrewe, P. L., Kaomar, K. M. (2001). Human Resource Management, A Strategic Approach, Third Edition, The Dryden Press, USA, pp. 541 - 549.

Bangladesh Bureau of Statistics (BBS), Statistics and Informatics Division (SID), Ministry of Planning, Updated upto 06, November, 2016

Becker, T.E. (1992). Foci and bases of commitment: Are they distinctions worth making? Academy of Management Journal, 35(1), 232-244. http:/ /dx.doi. org/10.2307/256481 
Beecham, S., Baddoo, N., Hall, T., Robinson, H. and Sharp, H. (2008). Motivation in software engineering: a systematic literature review. Information and Software Technology, 50 (910), 860-78.

Blum, M. L. and Naylor, J. C. (2004). 'Industrial Psychology Its Theoretical and Social Foundations,' Revised Edition,' CBS Publishers \& Distributors, 4596/1-A, 11 Darya Ganj, New Delhi, India, pp. $364-388$

Brierley, J. A. (1999). 'Accountants' Job Satisfaction: A MetaAnalysis.' British Accounting Review, Vol. 31, Issue: 1, pp. 63 -84 .

Carsten, J.M. and Spector, P.E. (1987). Unemployment, job satisfaction, and employee turnover: a meta-analytic test of the Muchinsky model. Journal of Applied Psychology, 72, 374-9.

Cave, A. H., Chung, W. and Choi, S. (2013). Determining the Factors Affecting Retention of Employees in Taiwanese Electronic's Firms-General Vs Repatriated Employees. International Journal of Academic Research in Business and Social Sciences, 3(1): 1 - 19.

Droussiotis, A. and Austin, J. (2007). Job satisfaction of managers in Cyprus. EuroMed Journal of Business, 2(2), $208-222$.

Eskildsen, J. K. \& Dahlgaard, J. J. (2000). "A Causal Model for Employee Satisfaction," Total Quality Management 11(8): 1081-1094.

Fox, S.R., \& Fallon, B.J. (2003). Modeling the effect of work/life balance on job satisfaction and turnover intentions. Symposium paper presented at the 5th Australian Industrial and Organisational Psychology Conference, Melbourne, Australia.

Furnham, A., Eracleous, A., and Chamorro-Premuzic, T., (2009). Personality, Motivation and Job Satisfaction: Herzberg meets the Big Five. Journal of Managerial Psychology, vol. 24, no. 8, pp. 765-79.

George, D. and Mallery, P. (2009). SPSS for Windows step by step: A simple guide and reference. 15.0 update (Eighth Edition). Boston: Allyn \& Bacon. P.231.

Giffen, R. (2015). Organizational Culture and Personality Type: Relationship with Person-organization Fit and Turnover Intention, A Dissertation Submitted to the Graduate Faculty in Partial Fulfillment of the Requirements for the Degree of Doctor of Philosophy, Iowa State University, USA, 1 - 161.

Gunlu, E. Aksarayli, M. Perçin, N.S. (2010). Job satisfaction and organizational commitment of hotel managers in Turkey. International Journal of Contemporary Hospitality Management, 22(5), 693 - 717.

Hellman, C. M. (1997). Job satisfaction and intent to leave. The Journal of Social Psychology, 137(6), 677-89.

Hoppock, R. and Spiegler, S. (1938). Job Satisfaction, Occupations: The Vocational Guidance Journal, 16(7), 636 - 643, DOI: 10.1002/j.2164 - 5892.1938.tb00348.x

Jesily, M. (2013). Job-Related Factors Vis-à-vis LaborManagement Relations, Prabandhan: Indian Journal of Management, Issue: March, pp. 27 - 33.
Joo, B.K and Park, S. (2010). Career satisfaction, organizational commitment, and turnover intention: The effects of goal orientation, organizational learning culture and developmental feedback. Leadership $\mathcal{E}$ Organization Development Journal, 31(6), 482 - 500.

Judge, T. A., Thoresen, C. J., Bono, J. E. and Patton, G. K (2001). The Job Satisfaction-Job Performance Relationship: A Qualitative and Quantitative Review, Psychological Bulletin, 127 (3): 376-407.

Kavanaugh, J., Duffy, J., A., and Lilly, J., (2006). The Relationship between Job Satisfaction and Demographic Variables for Healthcare Professionals. Management Research News, 29(6), 304-325.

Lambert, E.G., Hogan, N.L., \& Barton, S.M. (2001). The impact of job satisfaction on turnover intent: A test of a structural measurement model using a national sample of workers. Social Science Journal, 38(2), 233-250. http:/ / dx.doi.org/10.1016/ S0362-3319(01)00110-0

Lim, S. (2008). Job satisfaction of information technology worker in academic libraries. Library and Information Science Research, 30(2), 115-21.

Locke, E. (1983). The nature and causes of job satisfaction. In M.D. Dunnette ((Ed.) Handbook of Industrial and Organizational Psychology, pp: 1297-1349. New York, NY: John Wiley and sons,Inc.

Lu, H., Alison E. While, K., and Barriball, L. (2001) Job satisfaction among nurses: a literature review. International Journal of Nursing Studies 42: 211-227

Lu, H., While, A. E., \& Barriball, K. L. (2005). Job satisfaction among nurses: a literature review. International journal of nursing studies, 42(2), 211-227. https:/ / doi.org/10.1016/j.ijnurstu.2004.09.003

Maghrabi, A. S. (1999). 'Assessing the Effect of Job Satisfaction on Managers.' International Journal of ValueBased Management, Vol. 12, Issue: 1, pp. 1-12.

Maghrabi, A. S. and Hayajneh, A. (1993). 'Job Satisfaction, Work Motivation, and Life Satisfaction among Saudi Managers.' International Journal of Management, Vol. 10, Issue: 4, pp. 433439.

Martin, J. K., and Miller, G. A. (1986). Job Satisfaction and Absenteeism: Organizational, Individual and Job-related Correlates. Work and Occupations, 13(1), pp. 33-46.

Mathieu, J. E. and Zajac, D. M. (1990). A review and metaanalysis of the antecedents, correlates, and consequences of organizational commitment. Psychological Bulletin, 108(2), 171-194

Meyer, J. P., Stanley, D. J., et al. (2002)." Affective, Continuance, and Normative Commitment to the Organization: A Metaanalysis of Antecedents, Correlates, and Consequences," Journal of Vocational Behavior 61: 20-52.

Mueller, C. W. and Kim, S. W. (2008). The contented female worker: Still a paradox? In K. A. Hegtvedt \& J. ClayWarner (Eds.), Justice: Advances in group processes Bingley, UK: Emerald Group Publishing Limited, 25,117-150. 
Muralidharan, C., Venkatram, R. and Krihnaveni, R. (2013). Impact of Job Satisfaction on Intention to Quit: A Study on Customer Service Providers in Commercial Banks. Prabandhan: Indian Journal of Management, 6(7): 15 - 25.

Naumann, E., (1992). A conceptual model of expatriate turnover. Journal of International Business Studies, 499-529.

Ng, T., W., H., and Sorensen, K., L., 2(008). Toward a Further Understanding of the Relationships between Perceptions of Support and Work Attitudes - A Meta-Analysis. Group and Organization Management, 33(3), 243-268.

Ngamkroeckjotia, C., Phanitchrattana, S. and Ounprechavanit, P. (2013). Factors affect Turnover Intention of Bangkok Air Conditioning Company. IRISET ICEMCE'2013 and ICHCES'2013, March 15-16, Pattaya, Thailand, $26-31$.

Paul, S.C. (2010). Job Satisfaction among newly recruited employees in multinational organizations. Journal of Psychology, 16(1), 67 - 80.

Poorna, D. B., Anandaraj, P. (2013). An Analysis of Stress among the Women Mill Workers in Dindigul District of Tamil Nadu, Prabandhan: Indian Journal of Management, Issue: September, pp. 16-27.

Radhakrishna, R.B. (2007). Tips for Developing and Testing Questionnaires/Instruments Volume 45//Number 1//Tools of the Trade//1TOT2, Journal of Extension, Website: https://joe.org/joe/2007february/tt2.php, Visted: $5^{\text {th }}$ September, 2017.

Rahman, S.M. (2012). An Analysis of Job Satisfaction of Teachers Working in Government Colleges in Bangladesh. Prabandhan: Indian Journal of Management, 5(12), $15-25$.

Rahman, S.M. and Begum, M.S. (2017). Factors Affecting Turnover Intention of Real Estate Employees in Bangladesh, Dhaka University Journal of Management, Vol. 8 - 11, Nos. 1\&2, $181-194$.

Roodt, G. (2004). Turnover Intentions. Unpublished Document: University of Johannesburg.
Schroder, R., (2008). Job Satisfaction of Employees at a Christian University. Journal of Research on Christian Education, 17, 225-246.

Skibba, J. S. (2002). 'Personality and Job Satisfaction: An Investigation of Central Wisconsin Firefighters. Interactions between Personality and Various Factors at a Local Fire Department.' The Graduate School University of Wisconsin-Stout Menomonie, WI 54751, USA. pp. 1 117.

Smith, P. C., Kendall, L. M., \& Hulin, C. L. (1969). The measurement of satisfaction in work and retirement. Chicago, IL: Rand McNally.

Sowmya, K. R. (2013). Job Satisfaction and Turnover Intention in Organization: A Study across Sectors in Inidan Perspective. Prabandhan: Indian Journal of Management, 6(7): 1 - 14.

Spector, P. E. (1985). "Measurement of Human Service Staff Satisfaction: Development of the Job Satisfaction Survey," American Journal of Community Psychology 13(6): 693-713.

Spector, P. E. (2006). 'Industrial and Organizational Psychology: Research and Practice.' Fourth Edition, John Wiley \& Sons, Inc. pp. $220-234$.

Tuten, T. L. and Neidermeyer, P.E. (2004). Performance, satisfaction and turnover in call centers: The effects of stress and optimism, Journal of Business Research 57, pp. $26-34$.

Wright, T.A. and Bonett, D.G. (2007). Job satisfaction and psychological well-being as nonadditive predictors of workplace turnover. Journal of Management, 33(2), 141-60.

Wu. X. (2012). Factors Influencing Employee Turnover Intention: The Case of Retail Industry in Bangkok, Thailand. Master of Business Administration Thesis. International College, University of the Thai Chamber of Commerce. Pp. $2-65$. 


\section{How to cite this article:}

Rahman, S. M. (2020). Relationship between Job Satisfaction and Turnover Intention: Evidence from Bangladesh. Asian Business Review, 10(2), 99-108. https://doi.org/10.18034/abr.v10i2.470 